\title{
MANAGEMENT OF ENDOCRINE DISEASE Bone disorders associated with acromegaly: mechanisms and treatment
}

\author{
Gherardo Mazziotti ${ }^{1,2}$, Andrea G A Lania ${ }^{1,2}$ and Ernesto Canalis ${ }^{3}$ \\ ${ }^{1}$ Department of Biomedical Sciences, Humanitas University, ${ }^{2}$ Endocrine, Diabetes and Andrology Unit, Humanitas \\ Clinical and Research Center, IRCCS, Rozzano, Milan, Italy, and ${ }^{3}$ Departments of Orthopaedic Surgery and Medicine, \\ The UConn Musculoskeletal Institute, UConn Health, Farmington, Connecticut, USA
}

Correspondence should be addressed to G Mazziotti Email

gherardo.mazziotti@ hunimed.eu

\section{Abstract}

Growth hormone (GH) and insulin-like growth factor-I (IGF-I) exert physiological actions on the skeleton throughout life, by stimulating longitudinal bone growth in children, the acquisition of bone mass during adolescence and the maintenance of skeletal architecture in adults. When GH and IGF-I are secreted in excess, bone remodeling is enhanced leading to deterioration of bone microstructure and impairment of bone strength. Indeed, acromegaly causes skeletal fragility, and vertebral fractures are reported in a remarkable number of subjects exposed to GH and IGF-I excess. The management of skeletal fragility in acromegaly is a challenge, since the awareness of this complication is low, the prediction of fracture risk is difficult to ascertain, the risk of fractures remains after the control of acromegaly and the effectiveness of bone-active drugs is unknown. This review is an update on bone disorders associated with acromegaly and provides a perspective of possible therapeutic approaches based on emerging pathophysiological and clinical information.

\section{Introduction}

Acromegaly is a chronic and disabling disease characterized by excessive secretion of growth hormone (GH) generally caused by a pituitary adenoma resulting in elevated circulating levels of GH and insulin-like growth factor (IGF-I) (1).

Under physiological conditions, GH and IGF-I are beneficial to skeletal health since they enhance
European Journal of Endocrinology

(2019) 181, R45-R56

\section{Invited Author's profile}

Gherardo Mazziotti, MD, PhD is an Associate Professor of Endocrinology at Humanitas University of Milan, Head of Metabolic Bone Diseases and Osteoporosis Section and bone specialist in the Pituitary Tumor Center of Excellence of Humanitas Research Center of Rozzano (MI), Italy. His main field of interest is the neuroendocrinology of bone and during the last 15 years, Dr Mazziotti has made several contributions to the understanding of the role of pituitary hormones, particularly growth hormone in bone metabolism.

(C) 2019 European Society of Endocrinology Printed in Great Britain longitudinal bone growth, as well as bone modeling and remodeling (2). Based on these physiological effects and the fact that subjects with acromegaly have characteristically enlarged bones, acromegaly has been overlooked as a risk factor for skeletal fragility and fractures $(3,4)$. Recently, this paradigm was revisited because of findings demonstrating that GH and IGF-I in 
excess may cause abnormalities in trabecular and cortical bone architecture leading to decreased bone strength and increased risk of vertebral fractures (VFs) (5).

The management of skeletal fragility in acromegaly is challenging since VFs are not predicted by changes in bone mineral density (BMD) (6), the fracture risk persists in subjects following the successful treatment of the disease $(7,8)$ and the efficacy and safety of bone-active drugs in acromegaly are unknown (5).

This review is an update on bone disorders associated with acromegaly and provides a perspective of possible therapeutic approaches based on emerging pathophysiological and clinical information.

\section{Physiology of the GH-IGF-I axis in the skeleton}

During the first two decades of life, GH and IGF-I play a central role in endochondral bone formation by stimulating chondrocyte proliferation and differentiation. These effects on the epiphyseal plate are paralleled by the actions of GH and IGF-I on bone modeling (Fig. 1), a process whereby bones are shaped or reshaped by the independent and uncoupled action of osteoblasts and osteoclasts. Bone modeling occurs either during skeletal development or after growth and throughout life $(9,10)$. GH and IGF-I also stimulate bone remodeling, a process of coupled bone resorption and formation, necessary to maintain calcium homeostasis and to remove potentially micro-damaged bone throughout life.

Bone remodeling is carried out in microscopic basic multicellular units (BMUs) by the activity of osteoclasts and osteoblasts $(11,12)$. Osteoclasts are multinucleated cells arising from mononuclear precursors of the hematopoietic lineage and are responsible for bone resorption, a process that takes 3-5 weeks. Thereafter, the resorbed surface attracts osteoblasts that fill the BMU with new matrix, in a process that takes 3-5 months. Osteoblasts derive from mesenchymal cells that reside in the bone marrow and they can differentiate further into lining cells or into osteocytes or can die by apoptosis $(13,14,15)$. Osteocytes have cytoplasmic processes that connect them among themselves or to other cells in the bone environment to form a communicating network that plays a role in maintaining the material properties and structural strength of bone (16). Osteocytes are responsible for skeletal responses to mechanical load and are a significant source of receptor activator of NF kappa B ligand (RANKL) (17).

\section{In vitro effects of GH and IGF-I on bone formation and resorption}

The GH receptor is expressed by chondrocytes and osteoblasts $(18,19,20,21)$ and its expression is under the control of IGF-I (22) and of IGF-binding proteins (IGFBPs) $(23,24)$. GH stimulates osteoblastogenesis directly or indirectly $(25,26,27)$. For example, GH suppresses the expression of fetal antigen 1 , the soluble form of deltalike-1, known to suppress fat and bone mass (27). GH also stimulates the expression of bone morphogenetic proteins, which along with Wnt play a role in enhancing osteoblastogenesis $(28,29,30)$. GH stimulates the carboxylation of osteocalcin, which is a marker of osteoblastic function (31).

Although GH may have direct effects on cells of the osteoblast lineage, most of the effects in osteoblasts and bone formation are mediated by the systemic form of IGF-I, synthesized in the liver under GH control (32).

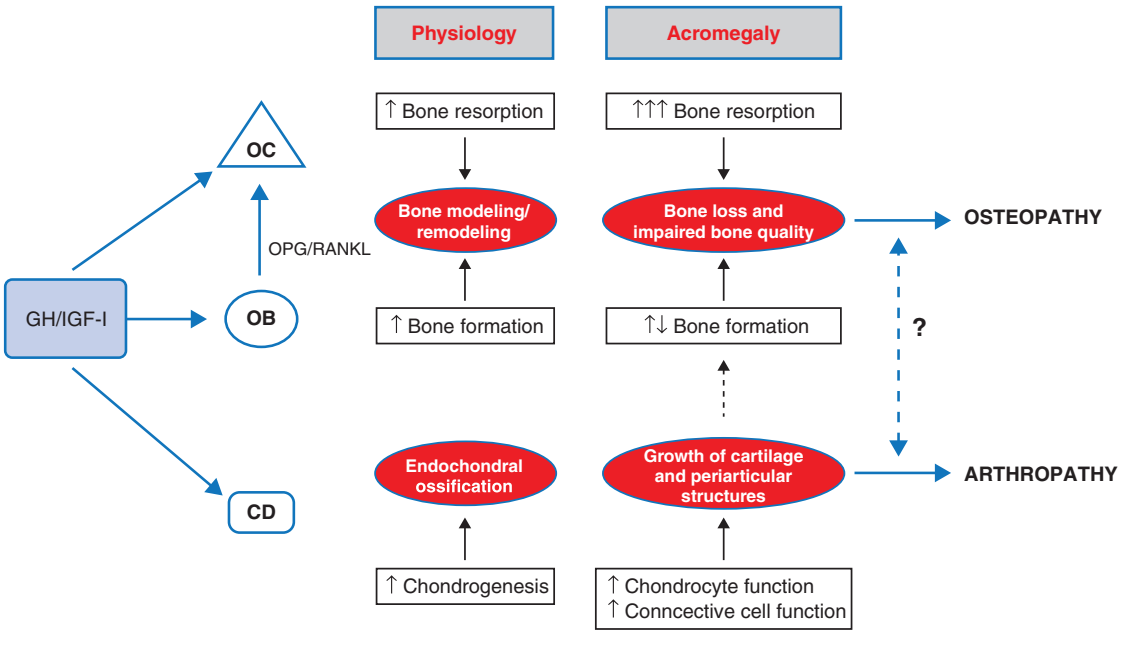

Figure 1

Effects of growth hormone $(\mathrm{GH})$ and insulin-like growth factor-I (IGF-I) on bone cells and cartilage in physiology and disease. $C D$, chondrocyte; $O B$, osteoblast; OC, osteoclast; OPG, osteoprotegerin; RANKL, Receptor activator of nuclear factor kappa-B ligand. 
It is important to note that the synthesis of IGF-I in osteoblasts is not enhanced by GH and is under the control of parathyroid hormone (PTH) $(33,34)$. IGF-I has modest effects on osteoblast differentiation and enhances the function of mature osteoblasts (35). IGF-I upregulates type I collagen transcription and decreases the synthesis of matrix metalloproteinase 13 , a collagen-degrading protease (36), ensuring the maintenance of appropriate levels of bone matrix and bone mass. IGF-1 stimulates the expression of RANKL and, as a consequence, osteoclastogenesis (37). The IGF-I receptor is present in preosteoclasts and mature osteoclasts $(38,39)$, and IGF-I enhances the formation of osteoclast-like cells in cultures of bone marrow macrophages (40).

The effects of IGF-I on bone are modulated by IGFBP-2 and -4. IGFBP-2 stimulates osteoblastogenesis $(41,42)$, whereas IGFBP-4 inhibits the differentiation of progenitor cells and the functions of osteoblasts and osteoclasts (43, 44). The latter effects may be counteracted by a concomitant increase of IGF-I bioavailability induced by IGFBP-4.

\section{In vivo effects of GH and IGF-I on bone formation and resorption}

Pre-clinical studies have indicated that systemic IGF-I is necessary to maintain cortical bone structure, whereas skeletal IGF-I appears to play a more significant role in the maintenance of cancellous bone (2). Mice carrying mutations in the GH-releasing hormone receptor (lit/lit mouse) or the GH receptor exhibit reduced cortical bone, but normal trabecular bone and this may be accounted for by the GH-independent local production of IGF-I $(2,45$, 46). Similarly, mice carrying a liver-specific $I g f 1$ deletion display a modest skeletal phenotype, characterized by a decrease in cortical volume, secondary to a reduction in periosteal bone formation (47). In contrast, the conditional deletion of the IGF1 receptor (Igf1r) in murine osteoblasts causes a decrease in bone formation and trabecular bone volume (48).

Consistent with the in vitro/ex vivo studies reporting direct stimulatory effects of IGFBP-2 on osteoblastogenesis $(41,42), I g f b p 2$-null mice have low osteocalcin levels, abnormalities in trabecular bone structure and reduction in mineralizing surface/bone surface (49). These effects are observed in male but not in female mice, possibly reflecting the protective effects of persistently high circulating IGF-I concentrations in female mice (50). Interestingly, recombinant IGFBP-2 stimulates bone formation and protects against the bone loss observed following ovariectomy and skeletal unloading in rats (51).
The effects of IGFBP-4 on the skeleton in vivo were evaluated in mice following the inactivation (43) or the overexpression of $I g f b p 4$, as well as the administration of recombinant IGFBP-4 (52). Igfbp4-null male mice have increased trabecular bone, whereas female Igfbp4-null mice have a decrease in trabecular bone volume. The reasons of these sex-related findings are unclear (43).

Consistent with the in vitro/ex vivo findings of the direct inhibitory effects of IGFBP-4 on osteoblastogenesis $(43,44)$, the transgenic overexpression of Igfbp4 in Bglapexpressing osteoblasts caused a decrease in bone formation rate and mineral apposition rate, associated with a significant reduction in osteoid volume, osteoid surface and osteoblast number (44). In contrast, mice administered recombinant IGFBP-4 exhibited enhanced bone formation possibly because of increased IGF bioavailability via an IGFBP-4 protease-dependent mechanism (52). Despite these observations, it seems that the prevalent effect of IGFBP-4, like that of IGFBP-5, is an inhibition of osteoblast function and bone formation $(53,54)$.

\section{Effects of GH and IGF-I on calcium-phosphate metabolism}

GH and IGF-1 regulate calcium and phosphate metabolism (55). These effects are mainly mediated by the activation of vitamin D by GH and IGF-I. GH stimulates calcitriol production in experimental animals (56) and men (57), an effect mediated by the stimulation of $1 \alpha$-hydroxylase in the proximal renal tubule by IGF-1 (58). The activation of vitamin D leads to a positive calcium balance secondary to an increase in intestinal calcium absorption (59) and renal calcium reabsorption in the distal tubule (60).

GH has phosphate-retaining actions in the kidney (55). The anti-phosphaturic effect of GH is due to an increase in the maximal tubular phosphate reabsorption rate and is independent of the actions of PTH (61). GH and IGF-I may influence circadian PTH secretion and pulsatility, but the physiological and pathophysiological implications of these effects remain unclear (62).

\section{Acromegaly: epidemiology and clinical aspects}

Acromegaly is a chronic disease with an estimated prevalence of 30-60 cases $/ 100,000$ and an incidence of approximately 3-4 cases/100,000 inhabitants (63). The sex ratio is close to 1 and the mean age at the time of diagnosis ranges between 40 and 50 years of age $(64,65)$. 
Acromegaly is characterized by the presence of symptoms and signs attributable to both GH and IGF-1 excess and to localized pituitary tumor mass effects. Because the diagnosis of acromegaly is often made approximately 10 years following the onset of the disease, the majority of affected individuals present with complications of the disease at the time of diagnosis (64). Comorbidities most frequently observed at the time of diagnosis are arterial hypertension, sleep apnea, impaired glucose tolerance or frank diabetes mellitus (66). Skeletal fragility is often not considered a complication of acromegaly.

The biochemical diagnosis of acromegaly is based upon the identification of persistently elevated serum levels of IGF1 (67). The random sampling of serum GH is not recommended in the diagnosis of acromegaly because $\mathrm{GH}$ secretion is pulsatile; however, a random serum sample documenting the coexistence of a serum GH level $<0.4 \mu \mathrm{g} / \mathrm{L}$ and a normal IGF1 level excludes the diagnosis of acromegaly (68). The lack of serum GH suppression during an oral glucose tolerance test confirms the diagnosis of acromegaly and this test should be performed in subjects with elevated or equivocal serum IGF1 levels (67).

\section{Bone disorders in untreated acromegaly}

\section{Effects of GH excess on bone formation and resorption}

In acromegaly, bone turnover is enhanced with a greater increase in bone resorption than in bone formation (6). The predominant effects of GH excess on bone resorption were reported in several studies evaluating biochemical markers of bone turnover $(69,70,71)$. The increased bone turnover is directly related to the levels of circulating $\mathrm{GH}$ and IGF-I (40). The increased bone remodeling is likely due to the actions of IGF-I on the induction of RANKL leading to enhanced osteoclastogenesis $(40,72,73)$. Analyzing gene expression in sphenoid bone tissue samples of subjects with acromegaly, Belaya et al. suggested that GH excess may induce mesenchymal stem cell commitment toward cartilage or adipocytes instead of toward mature osteoblasts (74). It was hypothesized that the cartilage growth induced by GH excess may influence osteoblast and osteoclast function directly in a way similar to the one occurring during normal endochondral ossification (74). One may speculate that acromegalic osteopathy and arthropathy share common pathophsyiological mechanisms (Fig. 1), as proposed in individuals with concominant osteoarthritis and osteoporosis $(75,76)$.

\section{Effects of GH excess on bone histomorphometry and architecture}

The increase in bone turnover in acromegaly may lead to bone loss and abnormalities in bone structure. Transgenic mouse models overexpressing GH under the control of a metallothionein 1 transcriptional regulatory element exhibit markedly increased bone resorption and impaired trabecular and cortical bone architecture and mechanical competence $(77,78)$. Abnormalities in bone structure also are found in subjects with acromegaly. Indeed, seminal human studies using histomorphometric analysis revealed an increase in trabecular and cortical bone mass and high activity of osteoclasts and osteoblasts at the tissue level (79). However, recent work using microarchitectural and histomorphometric analysis has allowed a better understanding of the trabecular and cortical bone structural changes in acromegaly (80). Dalle Carbonare et al. recently described reduced trabecular bone volume, trabecular thickness and increased trabecular separation demonstrating decreased cancellous bone; cortical thickness was increased, but the cortical bone was porous in subjects with acromegaly and VFs compared to subjects without acromegaly (81). These results were consistent with previous data reporting abnormal bone architecture and altered biomechanical competence in subjects with active acromegaly (82). Using the less invasive high-resolution-peripheral quantitative computerized tomography (HR-pQCT), Madeira et al. reported decreased trabecular density, trabecular bone volume/tissue volume and trabecular number in the distal tibia and radius of subjects with acromegaly. These structural alterations closely correlated with the gonadal function of the subjects studied (83). However, subsequent work demonstrated abnormalities in trabecular bone microstructure and strength in active acromegalic patientseven when gonadal function was normal $(84,85,86)$. In addition to these changes in cancellous bone, the cortical bone compartment is affected, and GH excess is associated with increased cortical porosity/pore volume $(81,84,87)$ and decreased cortical density (85).

\section{Effects of GH excess on fracture risk}

The structural abnormalities in cancellous bone of subjects with acromegaly explain the increased incidence of VFs but do not seem to be a cause of fragility fractures in long bones $(3,4,66)$. The fragility of the peripheral skeleton is mainly related to the properties of cortical bone, which is affected in a distinct manner by GH, possibly 
because bone remodeling is less active in cortical than in trabecular bone. Moreover, GH hypersecretion induces periosteal bone formation with a consequent increase in cortical bone mass, which may in part counteract the potential negative effects of high bone remodeling that lead to a porous cortical bone. Interestingly, the moment of inertia of the femoral bone is high in an experimental model of acromegaly (88). GH excess causes vertebral fragility, which is related to focal areas of erosion creating stress risers on trabeculae. These effects are closely related to high bone remodeling, an activity that takes place mainly in cancellous bone. Applying a radiological and morphometric approach (89) (Fig. 2), Bonadonna et al. described for the first time an increase in the prevalence of VFs in post-menopausal women with acromegaly (90). In addition, cross-sectional studies confirmed this finding consistently and demonstrated an increased incidence of VFs in pre-menopausal women and male subjects with acromegaly $(91,92,93,94,95)$. The overall median prevalence of VFs in acromegaly is about $40 \%$, a fracture risk which is three- to eight-fold greater compared to control subjects (6). Interestingly, the prevalence of VFs is slightly greater in men than in women (5). A recent study provided suggestive evidence that VFs are a consequence of the skeletal exposure to GH and IGF-I excess, since the risk of fractures was correlated with the duration of active
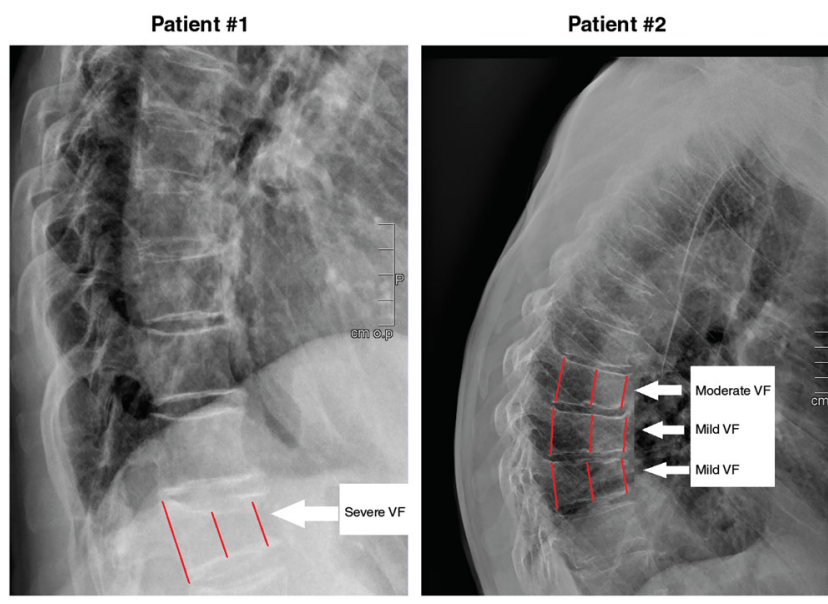

\section{Figure 2}

Vertebral X-rays of two subjects with acromegaly and vertebral fractures (arrows). Vertebral fractures were identified marking the vertebral body with six points to describe the vertebral shape and height. According to a quantitative morphometric approach, VFs were defined mild, moderate and severe based on a height ratio decrease of $20-25 \%, 25-40 \%$ and more than $40 \%$, respectively (89). The two subjects consented to the publication of X-rays. disease (7). Moreover, a higher incidence of fractures was found in individuals harboring an exon-3 deficient GH receptor that has increased affinity for GH (96).

VFs are not a simple radiological finding but they should be considered a marker of skeletal fragility, since an association between fractures and abnormalities in bone microstructure was found following the analysis of bone samples from individuals with acromegaly by histomorphometry, tridimensional dual-energy X-ray absorptiometry (DXA) of the proximal femur and peripheral HR-QCT of the bone structure at the distal radius $(81,85,87)$.

Noteworthy, VFs develop more frequently in the thoracic spine and they are often anterior wedge fractures (91), possibly contributing to the kyphosis of subjects with acromegaly (97). The fact that more than $50 \%$ of individuals with fractures have either multiple or severe VFs (95), may predispose subjects with fractures to have back pain, impaired quality of life and a possible worse outcome of cardiopulmonary complications in acromegaly $(98,99)$.

\section{Effects of GH excess on calcium and phosphate metabolism}

Active acromegaly is associated with mild hyperphosphatemia and a tendency toward hypercalcemia and hypercalciuria $(55,72)$, closely related to increased calcitriol-stimulated phosphate and calcium absorption in the gut and to the direct antiphosphaturic action of IGF-I (55). Hypercalciuria may be considered, at least in part, a marker of skeletal fragility reflecting the increased bone turnover induced by GH excess (55).

Notwithstanding the stimulatory effects of GH and IGF-I on vitamin D activation by the kidney (55), hypovitaminosis $\mathrm{D}$ is found in patients with acromegaly consistently $(100,101)$. There is evidence suggesting lower peripheral bioavailability of vitamin $\mathrm{D}$ in acromegaly because of an increase in serum levels of vitamin D-binding protein $(102,103)$. GH excess influences PTH pulsatility with prolongation of pulse duration and increase in pulse mass (104); however, the skeletal implications of these effects are unclear.

\section{Bone disorders in treated acromegaly}

The therapeutic goals in acromegaly are the normalization of the hormonal excess, the removal of the tumor and the control of the clinical manifestations of the 
disease. Altogether, these lead to a decrease in mortality. Transsphenoidal surgery is considered the first line of treatment, especially in subjects harboring fully resectable tumors or those with neurological complications, such as visual impairment (67).

Medical treatment is based upon the administration of either long-acting somatostatin analogs (SSAs) or GH receptor antagonists (GRAs). These are usually prescribed in patients with persistent disease after surgery or in selected cases as a first line of treatment (67). Firstgeneration (i.e. octreotide LAR and lanreotide autogel) and second-generation (pasireotide) SSAs are effective in controlling GH secretion and tumor size, whereas the GRA pegvisomant normalizes IGF-I levels without any significant effect on tumor mass (105). Stereotactic radiosurgery may be used as adjuvant or alternative therapy in subjects with inoperable or residual disease or in those who are not surgical candidates (67).

\section{Effects of acromegaly therapy on bone turnover, bone structure and calcium- phosphate metabolism}

Cross-sectional and prospective studies have demonstrated a decrease in serum levels of biochemical markers of bone turnover following the biochemical control of acromegaly (5). However, it is unclear whether the decrease in bone turnover is accompanied by an improvement in bone structure, and a reduction in fracture risk. Recent studies hypothesized that osteoblastogenesis may be impaired in subjects with controlled acromegaly, but the studies do not offer a direct proof that osteoblast number or function is altered in these individuals $(74,106,107)$. Dalle Carbonare et al. reported decreased osteoblast number and function and reduced osteocyte number in bone samples from patients with controlled acromegaly compared to those with active disease, but the impact of these histomorphometric findings on fracture risk was uncertain since all subjects included in the study had VFs (81). Further findings to support the concept that skeletal fragility persists notwithstanding biochemical control of acromegaly are the impairment of trabecular microstructure as assessed by DXA measurement of trabecular bone score (TBS) (108) and altered tissuelevel properties of cortical bone as measured by impact microindentation in individuals with treated acromegaly (109). These may be the result of permanent or irreversible alterations in bone structure or persistently increased bone remodeling.
The biochemical control of acromegaly is usually accompanied by a significant and rapid decrease in serum calcium and phosphorus with the normalization of hypercalciuria and secondary increase in serum PTH $(72,110,111)$. The decrease in serum phosphate after the biochemical control of acromegaly was not related to changes in serum fibroblast growth factor-23 (112), a phosphaturic factor that promotes renal phosphate excretion and inhibits renal synthesis of dihydroxyvitamin $\mathrm{D}_{3}$ (113). The impact of the alterations in calcium and phosphate metabolism on skeletal function is unknown.

\section{Effects of acromegaly therapy on fracture risk}

The persistent abnormalities in bone structure explain why fracture risk persists in some patients with cured acromegaly $(7,8)$, particularly, when hypogonadism is present $(7,114)$, diabetes mellitus coexists $(115)$ or when pre-existing (i.e., prevalent) VFs are identified $(7,8)$. The latter finding is consistent with the concept that VFs are a marker of skeletal fragility in acromegaly $(116,117)$. Based on the hypothesis that the drugs used in acromegaly may have direct effects on peripheral targets independent of the biochemical control of the disease $(118,119,120)$, some studies investigated the possible effects of SSAs and pegvisomant on fracture risk in acromegaly $(114,121)$. However, the results of these studies were inconclusive since the design did not allow to discriminate the skeletal effects of the drugs from those on the activity of the underlying disease.

\section{Proposed approach to subjects with acromegaly-induced skeletal fragility}

\section{Diagnosis of osteopathy in acromegaly}

In clinical practice, measurement of BMD at the lumbar spine, total hip and femoral neck by DXA is the mainstay for the diagnosis of osteoporosis and prediction of fracture risk (122). Unfortunatly, this approach has not been validated in acromegaly, where abnormalities of bone microarchitecture associated with GH hypersecretion are not captured by BMD. Degenerative joint alterations, characterized by osteophyte formation and facet-joint hypertrophy may lead to an overestimation of BMD measured at the lumbar spine (5). Moreover, BMD could be influenced by the bone enlargement caused by GH excess (123). Because of these reasons, a limited number of subjects exposed to GH excess have decreased BMD, 
and bone density is not a reliable predictor of fracture risk in acromegaly (6). Subjects with acromegaly may develop VFs even in the presence of normal BMD $(90,91,95)$.

Volumetric BMD measured by QCT is used to determine the bone density of the trabecular compartment independent from the cortical bone and is not influenced by changes in the size of bones. Volumetric BMD was reported to be decreased in acromegaly $(124,125)$, but the value of this finding in predicting VF risk is unknown, in part due to a lack of specific and standardized cut-offs for identifying individuals with osteoporosis. A more accurate evaluation of bone microstructural alterations associated with GH hypersecretion and VFs may be provided by HR-QCT $(83,87)$, but the high cost and increased radiation dose limit their use in clinical practice. However, there are more feasible diagnostic techniques that may assist the clinician in the identification of acromegalics with skeletal fragility and predisposed to VFs. A non-invasive bone structure assessment using DXA images termed 3D-SHAPER was developed to analyze the cortical bone layer independent of the trabecular macrostructure at the proximal femur (126) and lumbar vertebrae (127). This approach demonstrated a decrease in cortical volumetric BMD at the proximal femur in acromegalic subjects with VFs compared to those without fractures (85). Another simple and feasible approach to assess bone structure using DXA images is the measurement of TBS, a graylevel textural metric that can be extracted from the $2 \mathrm{D}$ lumbar spine DXA image. TBS captures the mean rate of pixel gray-level variations in the DXA image. A high TBS value reflects better trabecular bone structure, whereas a low TBS value indicates impaired structure that is proned to fractures (128). Low TBS values are found in subjects with acromegaly and VFs (85). Based on this knowledge, non-invasive 3D-SHAPER and TBS assessments could be valuable in the assessment and management of individuals with acromegalic osteopathy.

The high incidence of fractures related to $\mathrm{GH}$ hypersecretion (6), untreated hypogonadism (7), diabetes mellitus (115) and pre-existing $\operatorname{VFs}(7,8)$ are all compelling reasons for a direct evaluation for the presence of VFs by a morphometric approach in all subjects with acromegaly at the time of diagnosis and during their follow-up (i.e., every 18 months) depending on the risk profile at baseline. Quantitative morphometry is performed on spinal X-ray images (129), although a quantitative approach may also be applied to images of the spine acquired either by DXA (130) or by chest X-rays $(99,131)$. VFs are identified by describing the shape and heights of vertebral bodies.
According to a quantitative morphometric approach, VFs are defined as mild, moderate and severe based on a height ratio decrease of $20-25 \%, 25-40 \%$ and over $40 \%$, respectively (89). Noteworthy, the diagnosis of mild VFs in acromegaly may be challenging particularly when they involve the upper thoracic vertebrae, due to the presence of osteophytes and deformities of vertebral bodies caused by arthropathy (Fig. 2). Arthropathy is one of the most prevalent and invalidating complications of acromegaly, affecting both weight- and non-weightbearing joints (132).

\section{Treatment of osteopathy in acromegaly}

No studies have been performed on the effectiveness and safety of bone-active drugs in acromegaly; therefore, no specific guidelines have been developed. The treatment of acromegalic osteopathy cannot be evidence based. However, some recommendations based on the experience of one of the co-authors (GM) and results of recent clinical studies can be considered.

The fundamental question is who may benefit from a treatment with bone-active drugs? The early identification of individuals with VFs may offer guidance on the subsequent therapeutic approach. Based on the results of a few longitudinal studies on VFs $(7,8)$, anti-osteoporotic therapy may be considered in subjects with either multiple or moderate-severe pre-existing VFs, regardless of the state of the underlying acromegaly. In fact, progression of VFs has been observed in individuals with controlled/cured acromegaly with two or more prevalent VFs (8) and in those subjects with a higher spine deformity index (7), which is an composite measure of the grade of VFs calculated by summing the score of each individual fracture (133). The management of acromegalic subjects with single mild VFs is more uncertain, because of their lower predictive value and the potential pitfalls in the diagnosis of these fractures in the presence of arthropathy. In these cases, the analysis of bone structure by non-invasive diagnostic tools, such as TBS or 3D-SHAPER DXA may assist clinicians in the identification of vertebral deformities associated with skeletal fragility (85). This could serve as a guide for therapeutic decision making, particularly in males with coexistent risk factors for fractures, such as untreated hypogonadism (7) and diabetes mellitus (115). Bonetargeted therapy may also be considered in individuals without VFs but with persistently active acromegaly in an effort to prevent fractures secondary to the continued skeletal exposure to GH excess. Based on the results from longitudinal studies $(7,121)$, it may be reasonable to start 
anti-osteoporotic drugs in patients without prevalent factures when acromegaly is persistently active despite multimodal therapy for one year or longer.

The choice of bone-active drugs to use in acromegaly is another challenge, since no studies have been performed to test their efficacy and safety in this clinical setting. Based on pathophysiological considerations, inhibitors of osteoclastogenesis and bone resorption, such as denosumab and bisphosphonates, may counteract the effects of GH and IGF-I excess on bone remodeling. Anabolic therapy with teriparatide or abaloparatide might not be effective, due to their stimulatory effects on bone remodeling and on the synthesis of IGF-I by the skeleton. However, when VFs progress despite the biochemical control of acromegaly and when bone remodeling is not enhanced $(6,72)$, anabolic therapy may be considered to restore the trabecular bone microstructure and prevent additional fractures.

\section{Conclusions}

Osteopathy is an emerging complication of acromegaly, characterized by increased bone turnover, profound abnormalities in trabecular bone structure and high risk of VFs. These skeletal abnormalities are usually accompanied by mild hyperphosphatemia and a tendency toward hypercalcemia and hypercalciuria. Treatment of acromegaly improves but does not restore skeletal architecture and the risk of VFs persists even in selected subjects with controlled/cured acromegaly. Clinical awareness of this complication of acromegaly is necessary due to the potential negative impact of VFs on quality of life and cardio-respiratory function as well as an increased risk of mortality. Studies are needed to identify the determinants of skeletal fragility in active and controlled acromegaly and to evaluate the effectiveness and safety of bone-active drugs in this clinical setting.

\section{Declaration of interest}

$G M$ received consultant fees from Ipsen SPA and Novartis Farma and speaker honoraria from Eli Lilly; A G A L received research grants and speaker honoraria from Ipsen SPA, Pfizer and Novartis Pharma; E C has nothing to declare.

\section{Funding}

This research did not receive any specific grant from any funding agency in the public, commercial or not-for-profit sector.

\section{Acknowledgements}

The author thanks Mary Yurczak for secretarial assistance.

\section{References}

1 Ben-Shlomo A \& Melmed S. Acromegaly. Endocrinology and Metabolism Clinics of North America 200837 101-122. (https://doi. org/10.1016/j.ecl.2007.10.002)

2 Giustina A, Mazziotti G \& Canalis E. Growth hormone, insulin-like growth factors, and the skeleton. Endocrine Reviews 200829 535-559. (https://doi.org/10.1210/er.2007-0036)

3 Vestergaard P, Jorgensen JO, Hagen C, Hoeck HC, Laurberg P, Rejnmark L, Brixen K, Weeke J, Andersen M, Conceicao FL et al. Fracture risk is increased in patients with GH deficiency or untreated prolactinomas - a case-control study. Clinical Endocrinology 200256 159-167. (https://doi.org/10.1046/j.0300-0664.2001.01464.x)

4 Vestergaard P \& Mosekilde L. Fracture risk is decreased in acromegaly - a potential beneficial effect of growth hormone. Osteoporosis International 200415 155-159. (https://doi.org/10.1007/s00198-003-1531-z)

5 Mazziotti G, Frara S \& Giustina A. Pituitary diseases and bone. Endocrine Reviews 201839 440-488. (https://doi.org/10.1210/er.201800005)

6 Mazziotti G, Biagioli E, Maffezzoni F, Spinello M, Serra V, Maroldi R, Floriani I \& Giustina A. Bone turnover, bone mineral density, and fracture risk in acromegaly: a meta-analysis. Journal of Clinical Endocrinology and Metabolism 2015100 384-394. (https://doi. org/10.1210/jc.2014-2937)

7 Mazziotti G, Bianchi A, Porcelli T, Mormando M, Maffezzoni F, Cristiano A, Giampietro A, De Marinis L \& Giustina A. Vertebral fractures in patients with acromegaly: a 3-year prospective study. Journal of Clinical Endocrinology and Metabolism 201398 3402-3410. (https://doi.org/10.1210/jc.2013-1460)

8 Claessen KM, Kroon HM, Pereira AM, Appelman-Dijkstra NM, Verstegen MJ, Kloppenburg M, Hamdy NA \& Biermasz NR. Progression of vertebral fractures despite long-term biochemical control of acromegaly: a prospective follow-up study. Journal of Clinical Endocrinology and Metabolism 201398 4808-4815. (https:// doi.org/10.1210/jc.2013-2695)

9 Kobayashi S, Takahashi HE, Ito A, Saito N, Nawata M, Horiuchi H, Ohta $\mathrm{H}$, Ito A, Iorio R, Yamamoto $\mathrm{N}$ et al. Trabecular minimodeling in human iliac bone. Bone 200332 163-169. (https://doi. org/10.1016/S8756-3282(02)00947-X)

10 Langdahl B, Ferrari S \& Dempster DW. Bone modeling and remodeling: potential as therapeutic targets for the treatment of osteoporosis. Therapeutic Advances in Musculoskeletal Disease 20168 225-235. (https://doi.org/10.1177/1759720X16670154)

11 Parfitt AM. The bone remodeling compartment: a circulatory function for bone lining cells. Journal of Bone and Mineral Research 200116 1583-1585. (https://doi.org/10.1359/jbmr.2001.16.9.1583)

12 Mazziotti G, Bilezikian J, Canalis E, Cocchi D \& Giustina A. New understanding and treatments for osteoporosis. Endocrine 201241 58-69. (https://doi.org/10.1007/s12020-011-9570-2)

13 Bianco P \& Gehron Robey P. Marrow stromal stem cells. Journal of Clinical Investigation 2000105 1663-1668. (https://doi.org/10.1172/ JCI10413)

14 Canalis E. The fate of circulating osteoblasts. New England Journal of Medicine 2005352 2014-2016. (https://doi.org/10.1056/ NEJMe058080)

15 Park D, Spencer JA, Koh BI, Kobayashi T, Fujisaki J, Clemens TL, Lin CP, Kronenberg HM \& Scadden DT. Endogenous bone marrow MSCs are dynamic, fate-restricted participants in bone maintenance and regeneration. Cell Stem Cell 201210 259-272. (https://doi. org/10.1016/j.stem.2012.02.003)

16 Seeman E \& Delmas PD. Bone quality - the material and structural basis of bone strength and fragility. New England Journal of Medicine 2006354 2250-2261. (https://doi.org/10.1056/NEJMra053077)

17 O'Brien CA, Nakashima T \& Takayanagi H. Osteocyte control of osteoclastogenesis. Bone 201354 258-263. (https://doi.org/10.1016/j. bone.2012.08.121) 
18 Barnard R, Ng KW, Martin TJ \& Waters MJ. Growth hormone (GH) receptors in clonal osteoblast-like cells mediate a mitogenic response to GH. Endocrinology 1991128 1459-1464. (https://doi.org/10.1210/ endo-128-3-1459)

19 Werther GA, Haynes K, Edmonson S, Oakes S, Buchanan CJ, Herington AC \& Waters MJ. Identification of growth hormone receptors on human growth plate chondrocytes. Acta Paediatrica Supplement 199382 (Supplement 391) 50-53. (https://doi. org/10.1111/j.1651-2227.1993.tb12929.x)

20 Kassem M, Mosekilde L \& Eriksen EF. Growth hormone stimulates proliferation of normal human bone marrow stromal osteoblast precursor cells in vitro. Growth Regulation 1994 4 131-135.

21 Nilsson A, Swolin D, Enerback S \& Ohlsson C. Expression of functional growth hormone receptors in cultured human osteoblastlike cells. Journal of Clinical Endocrinology and Metabolism $1995 \mathbf{8 0}$ 3483-3488. (https://doi.org/10.1210/jcem.80.12.8530587)

22 Leung K, Rajkovic IA, Peters E, Markus I, Van Wyk JJ \& Ho KK. Insulin-like growth factor I and insulin down-regulate growth hormone $(\mathrm{GH})$ receptors in rat osteoblasts: evidence for a peripheral feedback loop regulating GH action. Endocrinology $1996 \mathbf{1 3 7}$ 2694-2702. (https://doi.org/10.1210/endo.137.7.8770888)

23 Slootweg MC, Ohlsson C, Salles JP, de Vries CP \& Netelenbos JC. Insulin-like growth factor binding proteins-2 and -3 stimulate growth hormone receptor binding and mitogenesis in rat osteosarcoma cells. Endocrinology 1995136 4210-4217. (https://doi.org/10.1210/ endo.136.10.7545101)

24 Slootweg MC, Ohlsson C, van Elk EJ, Netelenbos JC \& Andress DL. Growth hormone receptor activity is stimulated by insulin-like growth factor binding protein 5 in rat osteosarcoma cells. Growth Regulation 19966 238-246.

25 Gevers EF, Loveridge N \& Robinson IC. Bone marrow adipocytes: a neglected target tissue for growth hormone. Endocrinology 2002143 4065-4073. (https://doi.org/10.1210/en.2002-220428)

26 Abdallah BM, Boissy P, Tan Q, Dahlgaard J, Traustadottir GA, Kupisiewicz K, Laborda J, Delaisse JM \& Kassem M. dlk1/FA1 regulates the function of human bone marrow mesenchymal stem cells by modulating gene expression of pro-inflammatory cytokines and immune response-related factors. Journal of Biological Chemistry 2007282 7339-7351. (https://doi.org/10.1074/jbc.M607530200)

27 Abdallah BM, Ding M, Jensen CH, Ditzel N, Flyvbjerg A, Jensen TG, Dagnaes-Hansen F, Gasser JA \& Kassem M. Dlk1/FA1 is a novel endocrine regulator of bone and fat mass and its serum level is modulated by growth hormone. Endocrinology $20071483111-3121$. (https://doi.org/10.1210/en.2007-0171)

28 Canalis E, Economides AN \& Gazzerro E. Bone morphogenetic proteins, their antagonists, and the skeleton. Endocrine Reviews 2003 24 218-235. (https://doi.org/10.1210/er.2002-0023)

29 Bennett CN, Longo KA, Wright WS, Suva LJ, Lane TF, Hankenson KD \& MacDougald OA. Regulation of osteoblastogenesis and bone mass by Wnt10b. PNAS 2005102 3324-3329. (https://doi.org/10.1073/ pnas.0408742102)

30 Krishnan V, Bryant HU \& Macdougald OA. Regulation of bone mass by Wnt signaling. Journal of Clinical Investigation 2006116 1202-1209. (https://doi.org/10.1172/JCI28551)

31 Hubina E, Lakatos P, Kovacs L, Szabolcs I, Racz K, Toth M, Szucs N \& Goth MI. Effects of 24 months of growth hormone (GH) treatment on serum carboxylated and undercarboxylated osteocalcin levels in GH-deficient adults. Calcified Tissue International 200474 55-59. (https://doi.org/10.1007/s00223-002-2149-4)

32 Ohlsson C, Bengtsson BA, Isaksson OG, Andreassen TT \& Slootweg MC. Growth hormone and bone. Endocrine Reviews 199819 55-79. (https://doi.org/10.1210/edrv.19.1.0324)

33 McCarthy TL, Centrella M \& Canalis E. Cyclic AMP induces insulinlike growth factor I synthesis in osteoblast-enriched cultures. Journal of Biological Chemistry 1990265 15353-15356.
34 Ohlsson C, Nilsson A, Isaksson O \& Lindahl A. Growth hormone induces multiplication of the slowly cycling germinal cells of the rat tibial growth plate. PNAS 199289 9826-9830. (https://doi. org/10.1073/pnas.89.20.9826)

35 Canalis E. Effect of insulinlike growth factor I on DNA and protein synthesis in cultured rat calvaria. Journal of Clinical Investigation 1980 66 709-719. (https://doi.org/10.1172/JCI109908)

36 Canalis E, Rydziel S, Delany AM, Varghese S \& Jeffrey JJ. Insulinlike growth factors inhibit interstitial collagenase synthesis in bone cell cultures. Endocrinology 1995136 1348-1354. (https://doi. org/10.1210/endo.136.4.7895645)

37 Mochizuki H, Hakeda Y, Wakatsuki N, Usui N, Akashi S, Sato T, Tanaka K \& Kumegawa M. Insulin-like growth factor-I supports formation and activation of osteoclasts. Endocrinology 1992131 1075-1080. (https://doi.org/10.1210/endo.131.3.1505451)

38 Hou P, Sato T, Hofstetter W \& Foged NT. Identification and characterization of the insulin-like growth factor I receptor in mature rabbit osteoclasts. Journal of Bone and Mineral Research 199712 534-540. (https://doi.org/10.1359/jbmr.1997.12.4.534)

39 Fiorelli G, Formigli L, Zecchi Orlandini S, Gori F, Falchetti A Morelli A, Tanini A, Benvenuti S \& Brandi ML. Characterization and function of the receptor for IGF-I in human preosteoclastic cells. Bone 199618 269-276. (https://doi.org/10.1016/87563282(95)00485-8)

40 Ueland T. GH/IGF-I and bone resorption in vivo and in vitro. European Journal of Endocrinology 2005152 327-332. (https://doi. org/10.1530/eje.1.01874)

41 DeMambro VE, Le PT, Guntur AR, Maridas DE, Canalis E, Nagano K, Baron R, Clemmons DR \& Rosen CJ. Igfbp2 deletion in ovariectomized mice enhances energy expenditure but accelerates bone loss. Endocrinology 2015156 4129-4140. (https://doi. org/10.1210/en.2014-1452)

42 Xi G, Wai C, DeMambro V, Rosen CJ \& Clemmons DR. IGFBP-2 directly stimulates osteoblast differentiation. Journal of Bone and Mineral Research 201429 2427-2438. (https://doi.org/10.1002/ jbmr.2282)

43 Maridas DE, DeMambro VE, Le PT, Nagano K, Baron R, Mohan S \& Rosen CJ. IGFBP-4 regulates adult skeletal growth in a sex-specific manner. Journal of Endocrinology 2017233 131-144. (https://doi. org/10.1530/JOE-16-0673)

44 Zhang M, Faugere MC, Malluche H, Rosen CJ, Chernausek SD \& Clemens TL. Paracrine overexpression of IGFBP-4 in osteoblasts of transgenic mice decreases bone turnover and causes global growth retardation. Journal of Bone and Mineral Research 200318 836-843. (https://doi.org/10.1359/jbmr.2003.18.5.836)

45 Zhou Y, Xu BC, Maheshwari HG, He L, Reed M, Lozykowski M, Okada S, Cataldo L, Coschigamo K, Wagner TE et al. A mammalian model for Laron syndrome produced by targeted disruption of the mouse growth hormone receptor/binding protein gene (the Laron mouse). PNAS 199794 13215-13220. (https://doi.org/10.1073/ pnas.94.24.13215)

46 Sims NA, Clement-Lacroix P, Da Ponte F, Bouali Y, Binart N, Moriggl R, Goffin V, Coschigano K, Gaillard-Kelly M, Kopchick J et al. Bone homeostasis in growth hormone receptor-null mice is restored by IGF-I but independent of Stat5. Journal of Clinical Investigation 2000106 1095-1103. (https://doi.org/10.1172/JCI10753)

47 Sjogren K, Sheng M, Moverare S, Liu JL, Wallenius K, Tornell J, Isaksson $\mathrm{O}$, Jansson JO, Mohan S \& Ohlsson C. Effects of liverderived insulin-like growth factor I on bone metabolism in mice. Journal of Bone and Mineral Research 200217 1977-1987. (https://doi. org/10.1359/jbmr.2002.17.11.1977)

48 Zhang M, Xuan S, Bouxsein ML, von Stechow D, Akeno N, Faugere MC, Malluche H, Zhao G, Rosen CJ, Efstratiadis A et al. Osteoblast-specific knockout of the insulin-like growth factor (IGF) receptor gene reveals an essential role of IGF signaling in bone 
matrix mineralization. Journal of Biological Chemistry 2002277 44005-44012. (https://doi.org/10.1074/jbc.M208265200)

49 DeMambro VE, Clemmons DR, Horton LG, Bouxsein ML, Wood TL, Beamer WG, Canalis E \& Rosen CJ. Gender-specific changes in bone turnover and skeletal architecture in igfbp-2-null mice. Endocrinology 2008149 2051-2061. (https://doi.org/10.1210/en.2007-1068)

50 Xi G, Rosen CJ \& Clemmons DR. IGF-I and IGFBP-2 stimulate AMPK activation and autophagy, which are required for osteoblast differentiation. Endocrinology 2016157 268-281. (https://doi. org/10.1210/en.2015-1690)

51 Conover CA, Johnstone EW, Turner RT, Evans GL, John Ballard FJ, Doran PM \& Khosla S. Subcutaneous administration of insulin-like growth factor (IGF)-II/IGF binding protein-2 complex stimulates bone formation and prevents loss of bone mineral density in a rat model of disuse osteoporosis. Growth Hormone and IGF Research 2002 12 178-183. (https://doi.org/10.1016/S1096-6374(02)00044-8)

52 Miyakoshi N, Qin X, Kasukawa Y, Richman C, Srivastava AK, Baylink DJ \& Mohan S. Systemic administration of insulin-like growth factor (IGF)-binding protein-4 (IGFBP-4) increases bone formation parameters in mice by increasing IGF bioavailability via an IGFBP-4 protease-dependent mechanism. Endocrinology 2001142 2641-2648. (https://doi.org/10.1210/endo.142.6.8192)

53 Devlin RD, Du Z, Buccilli V, Jorgetti V \& Canalis E. Transgenic mice overexpressing insulin-like growth factor binding protein-5 display transiently decreased osteoblastic function and osteopenia. Endocrinology 2002143 3955-3962. (https://doi.org/10.1210/ en.2002-220129)

54 Durant D, Pereira RM \& Canalis E. Overexpression of insulin-like growth factor binding protein-5 decreases osteoblastic function in vitro. Bone 200435 1256-1262. (https://doi.org/10.1016/j. bone.2004.08.011)

55 Kamenicky P, Mazziotti G, Lombes M, Giustina A \& Chanson P. Growth hormone, insulin-like growth factor-1, and the kidney: pathophysiological and clinical implications. Endocrine Reviews 2014 35 234-281. (https://doi.org/10.1210/er.2013-1071)

56 Spanos E, Barrett D, MacIntyre I, Pike JW, Safilian EF \& Haussler MR. Effect of growth hormone on vitamin D metabolism. Nature 1978 273 246-247. (https://doi.org/10.1038/273246a0)

57 Brown DJ, Spanos E \& MacIntyre I. Role of pituitary hormones in regulating renal vitamin D metabolism in man. BMJ 1980280 277-278. (https://doi.org/10.1136/bmj.280.6210.277)

58 Menaa C, Vrtovsnik F, Friedlander G, Corvol M \& Garabedian M. Insulin-like growth factor I, a unique calcium-dependent stimulator of 1,25-dihydroxyvitamin D3 production. Studies in cultured mouse kidney cells. Journal of Biological Chemistry 1995270 25461-25467. (https://doi.org/10.1074/jbc.270.43.25461)

59 Suzuki Y, Landowski CP \& Hediger MA. Mechanisms and regulation of epithelial $\mathrm{Ca} 2+$ absorption in health and disease. Annual Review of Physiology 200870 257-271. (https://doi.org/10.1146/annurev. physiol.69.031905.161003)

60 Kamenicky P, Blanchard A, Gauci C, Salenave S, Letierce A, Lombes M, Brailly-Tabard S, Azizi M, Prie D, Souberbielle JC et al. Pathophysiology of renal calcium handling in acromegaly: what lies behind hypercalciuria? Journal of Clinical Endocrinology and Metabolism 201297 2124-2133. (https://doi.org/10.1210/jc.20113188)

61 Corvilain J \& Abramow M. Effect of growth hormone on tubular transport of phosphate in normal and parathyroidectomized dogs. Journal of Clinical Investigation 196443 1608-1612. (https://doi. org/10.1172/JCI105036)

62 Chiavistelli S, Giustina A \& Mazziotti G. Parathyroid hormone pulsatility: physiological and clinical aspects. Bone Research 20153 14049. (https://doi.org/10.1038/boneres.2014.49)

63 Fernandez A, Karavitaki N \& Wass JA. Prevalence of pituitary adenomas: a community-based, cross-sectional study in Banbury
(Oxfordshire, UK). Clinical Endocrinology 201072 377-382. (https:// doi.org/10.1111/j.1365-2265.2009.03667.x)

64 Reid TJ, Post KD, Bruce JN, Nabi Kanibir M, Reyes-Vidal CM \& Freda PU. Features at diagnosis of 324 patients with acromegaly did not change from 1981 to 2006: acromegaly remains underrecognized and under-diagnosed. Clinical Endocrinology 201072 203-208. (https://doi.org/10.1111/j.1365-2265.2009.03626.x)

65 Burton T, Le Nestour E, Neary M \& Ludlam WH. Incidence and prevalence of acromegaly in a large US health plan database. Pituitary 201619 262-267. (https://doi.org/10.1007/s11102-015-0701-2)

66 Petrossians P, Daly AF, Natchev E, Maione L, Blijdorp K, SahnounFathallah M, Auriemma R, Diallo AM, Hulting AL, Ferone D et al. Acromegaly at diagnosis in 3173 patients from the Liege Acromegaly Survey (LAS) Database. Endocrine-Related Cancer 201724 505-518. (https://doi.org/10.1530/ERC-17-0253)

67 Katznelson L, Laws ER, Jr, Melmed S, Molitch ME, Murad MH, Utz A, Wass JA \& Endocrine Society. Acromegaly: an Endocrine Society clinical practice guideline. Journal of Clinical Endocrinology and Metabolism 2014 99 3933-3951. (https://doi.org/10.1210/jc.2014-2700)

68 Giustina A, Barkan A, Casanueva FF, Cavagnini F, Frohman L, Ho K, Veldhuis J, Wass J, Von Werder K \& Melmed S. Criteria for cure of acromegaly: a consensus statement. Journal of Clinical Endocrinology and Metabolism 200085 526-529. (https://doi.org/10.1210/ jcem.85.2.6363)

69 Stepan J, Marek J, Havranek T, Dolezal V \& Pacovsky V. Bone isoenzyme of serum alkaline phosphatase in acromegaly. Clinica Chimica Acta: International Journal of Clinical Chemistry 197993 355-363. (https://doi.org/10.1016/0009-8981(79)90285-7)

70 Scillitani A, Chiodini I, Carnevale V, Giannatempo GM, Frusciante V, Villella M, Pileri M, Guglielmi G, Di Giorgio A, Modoni S et al. Skeletal involvement in female acromegalic subjects: the effects of growth hormone excess in amenorrheal and menstruating patients. Journal of Bone and Mineral Research 199712 1729-1736. (https://doi. org/10.1359/jbmr.1997.12.10.1729)

71 Ueland T, Bollerslev J, Godang K, Muller F, Froland SS \& Aukrust P. Increased serum osteoprotegerin in disorders characterized by persistent immune activation or glucocorticoid excess - possible role in bone homeostasis. European Journal of Endocrinology 2001145 685-690. (https://doi.org/10.1530/eje.0.1450685)

72 Constantin T, Tangpricha V, Shah R, Oyesiku NM, Ioachimescu OC, Ritchie J \& Ioachimescu AG. Calcium and bone turnover markers in acromegaly: a prospective, controlled study. Journal of Clinical Endocrinology and Metabolism 2017102 2416-2424. (https://doi. org/10.1210/jc.2016-3693)

73 Ozer FF, Dagdelen S \& Erbas T. Relation of RANKL and OPG levels with bone resorption in patients with acromegaly and prolactinoma. Hormone and Metabolic Research 201850 562-567.

74 Belaya Z, Grebennikova T, Melnichenko G, Nikitin A, Solodovnikov A, Brovkina O, Grigoriev A, Rozhinskaya L, Lutsenko A $\&$ Dedov I. Effects of active acromegaly on bone mRNA and microRNA expression patterns. European Journal of Endocrinology 2018 178 353-364. (https://doi.org/10.1530/EJE-17-0772)

75 Maruotti N, Corrado A \& Cantatore FP. Osteoblast role in osteoarthritis pathogenesis. Journal of Cellular Physiology 2017232 2957-2963. (https://doi.org/10.1002/jcp.25969)

76 Komori T. Runx2, an inducer of osteoblast and chondrocyte differentiation. Histochemistry and Cell Biology 2018149 313-323. (https://doi.org/10.1007/s00418-018-1640-6)

77 Tseng KF \& Goldstein SA. Systemic over-secretion of growth hormone in transgenic mice results in a specific pattern of skeletal modeling and adaptation. Journal of Bone and Mineral Research 1998 13 706-715. (https://doi.org/10.1359/jbmr.1998.13.4.706)

78 Lim SV, Marenzana M, Hopkinson M, List EO, Kopchick JJ, Pereira M, Javaheri B, Roux JP, Chavassieux P, Korbonits M et al. Excessive growth hormone expression in male GH transgenic mice adversely 
alters bone architecture and mechanical strength. Endocrinology 2015 156 1362-1371. (https://doi.org/10.1210/en.2014-1572)

79 Halse J, Melsen F \& Mosekilde L. Iliac crest bone mass and remodelling in acromegaly. Acta Endocrinologica 198197 18-22. (https://doi.org/10.1530/acta.0.0970018)

80 Chappard D, Basle MF, Legrand E \& Audran M. New laboratory tools in the assessment of bone quality. Osteoporosis International 201122 2225-2240. (https://doi.org/10.1007/s00198-011-1573-6)

81 Dalle Carbonare L, Micheletti V, Cosaro E, Valenti MT, Mottes M, Francia G \& Davi MV. Bone histomorphometry in acromegaly patients with fragility vertebral fractures. Pituitary 201821 56-64. (https://doi.org/10.1007/s11102-017-0847-1)

82 Ueland T, Ebbesen EN, Thomsen JS, Mosekilde L, Brixen K, Flyvbjerg A \& Bollerslev J. Decreased trabecular bone biomechanical competence, apparent density, IGF-II and IGFBP-5 content in acromegaly. European Journal of Clinical Investigation 200232 122-128. (https://doi.org/10.1046/j.1365-2362.2002.00944.x)

83 Madeira M, Neto LV, de Paula Paranhos Neto F, Barbosa Lima IC, Carvalho de Mendonca LM, Gadelha MR \& Fleiuss de Farias ML. Acromegaly has a negative influence on trabecular bone, but not on cortical bone, as assessed by high-resolution peripheral quantitative computed tomography. Journal of Clinical Endocrinology and Metabolism 201398 1734-1741. (https://doi.org/10.1210/jc.2012-4073)

84 Silva PPB, Amlashi FG, Yu EW, Pulaski-Liebert KJ, Gerweck AV, Fazeli PK, Lawson E, Nachtigall LB, Biller BMK, Miller KK et al. Bone microarchitecture and estimated bone strength in men with active acromegaly. European Journal of Endocrinology 2017177 409-420. (https://doi.org/10.1530/EJE-17-0468)

85 Kuzma M, Vanuga P, Sagova I, Pavai D, Jackuliak P, Killinger Z, Binkley NC, Winzenrieth R, Genant HK \& Payer J. Non-invasive DXA-derived bone structure assessment of acromegaly patients: a cross-sectional study. European Journal of Endocrinology 2019180 201-211. (https://doi.org/10.1530/EJE-18-0881)

86 Hong AR, Kim JH, Kim SW, Kim SY \& Shin CS. Trabecular bone score as a skeletal fragility index in acromegaly patients. Osteoporosis International 201627 1123-1129. (https://doi.org/10.1007/s00198015-3344-2)

87 Maffezzoni F, Maddalo M, Frara S, Mezzone M, Zorza I, Baruffaldi F, Doglietto F, Mazziotti G, Maroldi R \& Giustina A. High-resolutioncone beam tomography analysis of bone microarchitecture in patients with acromegaly and radiological vertebral fractures. Endocrine 201654 532-542. (https://doi.org/10.1007/s12020-0161078-3)

88 Morimoto I, Kai K, Okada Y, Okimoto N, Uriu K, Akino K, Yamashita S, Nakamura T \& Eto S. Skeletal changes in rats bearing mammosomatotrophic pituitary tumors: a model of acromegaly with gonadal dysfunction. Bone 200026 255-261. (https://doi. org/10.1016/S8756-3282(99)00274-4)

89 Genant HK, Jergas M, Palermo L, Nevitt M, Valentin RS, Black D $\&$ Cummings SR. Comparison of semiquantitative visual and quantitative morphometric assessment of prevalent and incident vertebral fractures in osteoporosis the Study of Osteoporotic Fractures Research Group. Journal of Bone and Mineral Research 1996 11 984-996.

90 Bonadonna S, Mazziotti G, Nuzzo M, Bianchi A, Fusco A, De Marinis L \& Giustina A. Increased prevalence of radiological spinal deformities in active acromegaly: a cross-sectional study in postmenopausal women. Journal of Bone and Mineral Research 2005 20 1837-1844. (https://doi.org/10.1359/JBMR.050603)

91 Wassenaar MJ, Biermasz NR, Hamdy NA, Zillikens MC, van Meurs JB Rivadeneira F, Hofman A, Uitterlinden AG, Stokkel MP, Roelfsema F et al. High prevalence of vertebral fractures despite normal bone mineral density in patients with long-term controlled acromegaly. European Journal of Endocrinology 2011164 475-483. (https://doi. org/10.1530/EJE-10-1005)
92 Padova G, Borzi G, Incorvaia L, Siciliano G, Migliorino V, Vetri M $\&$ Tita P. Prevalence of osteoporosis and vertebral fractures in acromegalic patients. Clinical Cases in Mineral and Bone Metabolism $2011837-43$

93 Madeira M, Neto LV, Torres CH, de Mendonca LM, Gadelha MR \& de Farias ML. Vertebral fracture assessment in acromegaly. Journal of Clinical Densitometry 201316 238-243. (https://doi.org/10.1016/j. jocd.2012.06.002)

94 Brzana J, Yedinak CG, Hameed N \& Fleseriu M. FRAX score in acromegaly: does it tell the whole story? Clinical Endocrinology 2014 80 614-616. (https://doi.org/10.1111/cen.12262)

95 Mazziotti G, Bianchi A, Bonadonna S, Cimino V, Patelli I, Fusco A Pontecorvi A, De Marinis L \& Giustina A. Prevalence of vertebral fractures in men with acromegaly. Journal of Clinical Endocrinology and Metabolism 200893 4649-4655. (https://doi.org/10.1210/ jc.2008-0791)

96 Mormando M, Nasto LA, Bianchi A, Mazziotti G, Giampietro A, Pola E, Pontecorvi A, Giustina A \& De Marinis L. GH receptor isoforms and skeletal fragility in acromegaly. European Journal of Endocrinology 2014171 237-245. (https://doi.org/10.1530/EJE-140205)

97 de Herder WW. The history of acromegaly. Neuroendocrinology 2016 103 7-17. (https://doi.org/10.1159/000371808)

98 Ben-Shlomo A, Sheppard MC, Stephens JM, Pulgar S \& Melmed S. Clinical, quality of life, and economic value of acromegaly disease control. Pituitary 201114 284-294. (https://doi.org/10.1007/s11102011-0310-7)

99 Mazziotti G, Baracca M, Doga M, Porcelli T, Vescovi PP \& Giustina A. Prevalence of thoracic vertebral fractures in hospitalized elderly patients with heart failure. European Journal of Endocrinology 2012167 865-872. (https://doi.org/10.1530/EJE-12-0566)

100 Ajmal A, Haghshenas A, Attarian S, Barake M, Tritos NA, Klibanski A, Miller KK \& Nachtigall LB. The effect of somatostatin analogs on vitamin $\mathrm{D}$ and calcium concentrations in patients with acromegaly. Pituitary 201417 366-373. (https://doi.org/10.1007/s11102-0130514-0)

101 Halupczok-Zyla J, Jawiarczyk-Przybylowska A \& Bolanowski M. Patients with active acromegaly are at high risk of $25(\mathrm{OH})$ D deficiency. Frontiers in Endocrinology 20156 89. (https://doi. org/10.3389/fendo.2015.00089)

102 Mazziotti G, Maffezzoni F \& Giustina A. Vitamin D-binding protein: one more piece in the puzzle of acromegalic osteopathy? Endocrine 201652 183-186. (https://doi.org/10.1007/s12020-016-0890-0)

103 Altinova AE, Ozkan C, Akturk M, Gulbahar O, Yalcin M, Cakir N $\&$ Toruner FB. Vitamin D-binding protein and free vitamin D concentrations in acromegaly. Endocrine 201652 374-379. (https:// doi.org/10.1007/s12020-015-0789-1)

104 Mazziotti G, Cimino V, De Menis E, Bonadonna S, Bugari G, De Marinis L, Veldhuis JD \& Giustina A. Active acromegaly enhances spontaneous parathyroid hormone pulsatility. Metabolism: Clinical and Experimental 200655 736-740. (https://doi.org/10.1016/j. metabol.2006.01.009)

105 Leonart LP, Tonin FS, Ferreira VL, Fernandez-Llimos F \& Pontarolo R. Effectiveness and safety of pegvisomant: a systematic review and meta-analysis of observational longitudinal studies. Endocrine 2019 63 18-26. (https://doi.org/10.1007/s12020-018-1729-7)

106 Valassi E, Garcia-Giralt N, Malouf J, Crespo I, Llauger J, Diez-Perez A \& Webb SM. Circulating miR-103a-3p and miR-660-5p are associated with bone parameters in patients with controlled acromegaly. Endocrine Connections 20198 39-49. (https://doi.org/10.1530/EC-180482)

107 Valenti MT, Mottes M, Cheri S, Deiana M, Micheletti V, Cosaro E, Davi MV, Francia G \& Dalle Carbonare L. Runx2 overexpression compromises bone quality in acromegalic patients. Endocrine-Related Cancer 201825 269-277. (https://doi.org/10.1530/ERC-17-0523) 
108 Godang K, Olarescu NC, Bollerslev J \& Heck A. Treatment of acromegaly increases BMD but reduces trabecular bone score: a longitudinal study. European Journal of Endocrinology 2016175 155-164. (https://doi.org/10.1530/EJE-16-0340)

109 Malgo F, Hamdy NAT, Rabelink TJ, Kroon HM, Claessen KMJA, Pereira AM, Biermasz NR \& Appelman-Dijkstra NM. Bone material strength index as measured by impact microindentation is altered in patients with acromegaly. European Journal of Endocrinology 2017176 339-347. (https://doi.org/10.1530/EJE-16-0808)

110 Legovini P, De Menis E, Breda F, Billeci D, Carteri A, Pavan P $\&$ Conte N. Long-term effects of octreotide on markers of bone metabolism in acromegaly: evidence of increased serum parathormone concentrations. Journal of Endocrinological Investigation 199720 434-438. (https://doi.org/10.1007/BF03347998)

111 Parkinson C, Kassem M, Heickendorff L, Flyvbjerg A \& Trainer PJ. Pegvisomant-induced serum insulin-like growth factor-I normalization in patients with acromegaly returns elevated markers of bone turnover to normal. Journal of Clinical Endocrinology and Metabolism 200388 5650-5655. (https://doi.org/10.1210/jc.2003030772)

112 Ito N, Fukumoto S, Taguchi M, Takeshita A, Takeuchi Y, Yamada S $\&$ Fujita T. Fibroblast growth factor (FGF) 23 in patients with acromegaly. Endocrine Journal 200754 481-484. (https://doi. org/10.1507/endocrj.K06-217)

$113 \mathrm{Hu}$ MC, Shiizaki K, Kuro-o M \& Moe OW. Fibroblast growth factor 23 and klotho: physiology and pathophysiology of an endocrine network of mineral metabolism. Annual Review of Physiology 201375 503-533. (https://doi.org/10.1146/annurev-physiol-030212-183727)

114 Chiloiro S, Mormando M, Bianchi A, Giampietro A, Milardi D, Bima C, Grande G, Formenti AM, Mazziotti G, Pontecorvi A et al. Prevalence of morphometric vertebral fractures in 'difficult' patients with acromegaly with different biochemical outcomes after multimodal treatment. Endocrine 201859 449-453. (https://doi. org/10.1007/s12020-017-1391-5)

115 Mazziotti G, Gola M, Bianchi A, Porcelli T, Giampietro A, Cimino V, Doga M, Gazzaruso C, De Marinis L \& Giustina A. Influence of diabetes mellitus on vertebral fractures in men with acromegaly. Endocrine 201140 102-108. (https://doi.org/10.1007/s12020-0119486-x)

116 Mazziotti G, Doga M, Frara S, Maffezzoni F, Porcelli T, Cerri L, Maroldi R \& Giustina A. Incidence of morphometric vertebral fractures in adult patients with growth hormone deficiency. Endocrine 201652 103-110. (https://doi.org/10.1007/s12020-015-0738-z)

117 Lindsay R, Pack S \& Li Z. Longitudinal progression of fracture prevalence through a population of postmenopausal women with osteoporosis. Osteoporosis International 200516 306-312. (https://doi. org/10.1007/s00198-004-1691-5)

118 De Marinis L, Bianchi A, Mazziotti G, Mettimano M, Milardi D, Fusco A, Cimino V, Maira G, Pontecorvi A \& Giustina A. The longterm cardiovascular outcome of different GH-lowering treatments in acromegaly. Pituitary 200811 13-20. (https://doi.org/10.1007/ s11102-007-0062-6)

119 Mazziotti G \& Giustina A. Effects of lanreotide SR and autogel on tumor mass in patients with acromegaly: a systematic review. Pituitary 201013 60-67. (https://doi.org/10.1007/s11102-009-0169-z)

120 Giustina A, Mazziotti G, Torri V, Spinello M, Floriani I \& Melmed S. Meta-analysis on the effects of octreotide on tumor mass in acromegaly. PLoS ONE 20127 e36411. (https://doi.org/10.1371/ journal.pone.0036411)
121 Chiloiro S, Mazziotti G, Giampietro A, Bianchi A, Frara S, Mormando M, Pontecorvi A, Giustina A \& De Marinis L. Effects of pegvisomant and somatostatin receptor ligands on incidence of vertebral fractures in patients with acromegaly. Pituitary $20182 \mathbf{1}$ 302-308. (https://doi.org/10.1007/s11102-018-0873-7)

122 Schousboe JT, Shepherd JA, Bilezikian JP \& Baim S. Executive summary of the 2013 International Society for Clinical Densitometry Position Development Conference on bone densitometry. Journal of Clinical Densitometry 201316 455-466. (https://doi.org/10.1016/j. jocd.2013.08.004)

123 Ueland T, Fougner SL, Godang K, Schreiner T \& Bollerslev J. Serum GH and IGF-I are significant determinants of bone turnover but not bone mineral density in active acromegaly: a prospective study of more than 70 consecutive patients. European Journal of Endocrinology 2006155 709-715. (https://doi.org/10.1530/eje.1.02285)

124 Battista C, Chiodini I, Muscarella S, Guglielmi G, Mascia ML, Carnevale V \& Scillitani A. Spinal volumetric trabecular bone mass in acromegalic patients: a longitudinal study. Clinical Endocrinology 200970 378-382. (https://doi.org/10.1111/j.13652265.2008.03322.x)

125 Valassi E, Crespo I, Malouf J, Vilades D, Leta R, Llauger J, Urgell E, Aulinas A, Marin AM, Biagetti B et al. Epicardial fat is a negative predictor of spine volumetric bone mineral density and trabecular bone score in acromegaly. Endocrine 201653 860-864. (https://doi. org/10.1007/s12020-016-0945-2)

126 Humbert L, Martelli Y, Fonolla R, Steghofer M, Di Gregorio S, Malouf J, Romera J \& Barquero LM. 3D-DXA: assessing the femoral shape, the trabecular macrostructure and the cortex in 3D from DXA images. IEEE Transactions on Medical Imaging 201736 27-39. (https:// doi.org/10.1109/TMI.2016.2593346)

127 Lopez Picazo M, Magallon Baro A, Del Rio Barquero LM, Di Gregorio S, Martelli Y, Romera J, Steghofer M, Gonzalez Ballester MA \& Humbert L. 3-D subject-specific shape and density estimation of the lumbar spine From a single anteroposterior DXA image including assessment of cortical and trabecular bone. IEEE Transactions on Medical Imaging 201837 2651-2662. (https://doi.org/10.1109/ TMI.2018.2845909)

128 Ulivieri FM, Silva BC, Sardanelli F, Hans D, Bilezikian JP \& Caudarella R. Utility of the trabecular bone score (TBS) in secondary osteoporosis. Endocrine 201447 435-448. (https://doi.org/10.1007/ s12020-014-0280-4)

129 Mazziotti G, Maffezzoni F, Frara S \& Giustina A. Acromegalic osteopathy. Pituitary 201720 63-69. (https://doi.org/10.1007/ s11102-016-0758-6)

130 Clark EM, Carter L, Gould VC, Morrison L \& Tobias JH. Vertebral fracture assessment (VFA) by lateral DXA scanning may be costeffective when used as part of fracture liaison services or primary care screening. Osteoporosis International 201425 953-964. (https://doi. org/10.1007/s00198-013-2567-3)

131 Torti C, Mazziotti G, Soldini PA, Foca E, Maroldi R, Gotti D, Carosi G \& Giustina A. High prevalence of radiological vertebral fractures in HIV-infected males. Endocrine 201241 512-517. (https://doi. org/10.1007/s12020-011-9586-7)

132 Claessen KM, Mazziotti G, Biermasz NR \& Giustina A. Bone and joint disorders in acromegaly. Neuroendocrinology 2016103 86-95. (https:// doi.org/10.1159/000375450)

133 Crans GG, Genant HK \& Krege JH. Prognostic utility of a semiquantitative spinal deformity index. Bone 200537 175-179. (https://doi.org/10.1016/j.bone.2005.04.003)
Received 13 March 2019

Revised version received 1 May 2019

Accepted 15 May 2019 